\title{
А.А. Тишкин
}

\section{РЕЗУЛЬТАТЫ РАДИОУГЛЕРОДНОГО ДАТИРОВАНИЯ КУРГАНОВ ЖУЖАНСКОГО ВРЕМЕНИ ПАМЯТНИКА ЯЛОМАН-ІІ (ЦЕНТРАЛЬНЫЙ АЛТАЙ)}

\author{
Исследование выполнено при поддержке Российского научного фонда (проект № 16-18-10033 \\ «Формирование и эволюичия систем жизнеобеспечения у кочевых социумов Алтая и сопредельных территорий \\ в поздней Древности и Средневековье: комплексная реконструкция»).
}

\begin{abstract}
В письменных китайских источниках имеются сведения о Жужанском каганате, который господствовал во Внутренней Азии со второй половины IV в. до поражения его от тюрок в середине VI в. При этом археологических данных об этой кочевой державе чрезвычайно мало. Такая ситуация обычно объясняется слабой изученностью древних памятников в Монголии. На Алтае раскопаны объекты, которые датируются жужанским временем. Среди них шесть курганов исследованы автором на памятнике Яломан-II. В ходе изучения материалов самыми важными стали многочисленные находки предметов вооружения и конского снаряжения, в том числе впервые обнаруженные деревянные основы жестких седел без стремян. Для их датирования в разных лабораториях получены абсолютные датировки, которые представлены в данной статье.

Ключевые слова: Алтай; курган; жужанское время; радиоуглеродное датирование.
\end{abstract}

Археологические исследования, осуществленные на территории Алтая в последней трети XX в. и первые десятилетия XXI в., позволили сформировать существенный объем сведений, которые отражают период истории, чаще всего обозначаемый как «гунносарматское время» [1. С. $150 ; 2$. С. 3 ; 3. С. 158]. В результате заполнилась имевшаяся лакуна между археологически хорошо изученной пазырыкской культурой и тюркской общностью, известной еще и по письменным источникам [4, 5 и др.]. Интерпретация новых массовых материалов имела несколько подходов. Основным из них стало предложенное Ю.Т. Мамадаковым [6] выделение булан-кобинской археологической культуры [7]. Однако оно потребовало не только общих обоснований, но и более качественной проработки всех данных для понимания динамики развития данного явления.

В ходе формирования культурно-хронологической концепции для изучения древней и средневековой истории народов Алтая обозначилась необходимость синхронизации выделенных этапов обозначенной буланкобинской культуры с известными событиями, отраженными в письменных свидетельствах [3. С. 158-184; 8. С. 160-161]. Изучение имевшихся материалов показало, что население Алтая со II в. до н.э. по V в. н.э. испытывало серьезное влияние трех кочевых империй, которые последовательно господствовали во Внутренней Азии: хуннуской (сюннуской), сяньбийской и жужанской. Данное обстоятельство потребовало корректировки такого не совсем адекватного обозначения, как «гунносарматское время» [3. С. 158; 9], а также более детального рассмотрения каждого обозначенного этапа.

Предтюркский период в истории Азии всегда привлекал внимание исследователей. Однако имевшиеся сведения и их разная культурно-хронологическая атрибуция сдерживали процесс адекватного понимания генезиса тюркской общности и начала тюркской государственно- сти. Раскопки на Алтае археологических объектов жужанского (вторая половина IV - первая половина V в. н.э.) и раннетюркского (вторая половина $\mathrm{V}$ - первая половина VI в.) времени позволили положительно продвинуться в этом направлении [3. С. 185-197].

В 2003, 2007 и 2008 гг. под руководством автора статьи раскопаны шесть непотревоженных курганов на памятнике Яломан-II [10, 11 и др.]. Они соотносятся с периодом существования Жужанского каганата, известного по китайским письменным источникам $[5,12-$ 14 и др.]. Важность существенного количества материалов из раскопок указанного комплекса заключается в том, что археологических свидетельств о собственно жужанях крайне мало, что чаще всего объясняется слабой изученностью древних памятников на территории Монголии. Зафиксированные на Алтае предметы материальной культуры и данные о погребально-поминальной обрядности позволили приступить к реконструкции существовавшей тогда системы жизнеобеспечения [11]. Но для этого важно иметь подтвержденные хронологические показатели. Опираясь на типологические разработки и поиск датированных аналогий, удалось определить временные рамки и наполнить конкретным содержанием выделенный верх-уймонский этап (вторая половина IV - первая половина V в. н.э.) булан-кобинской археологической культуры [8. C. 161], обозначенный по изученному памятнику ВерхУймон, который исследовался в верховьях Катуни [15]. Кроме него, выявлена довольно представительная группа курганов, раскопанных в разных районах Алтая [3. С. 286; 8. С. 161]. Второй подход базировался на радиоуглеродном датировании и получении абсолютных датировок. Это было обусловлено не только решением периодизационных задач, но и более детальным выяснением времени появления на Алтае тех или иных категорий предметов или отдельных изделий (культур- 
но-хронологических индикаторов). Реализации такой программы способствовала имевшаяся масса вспомогательного научного материала органического происхождения и возможности изучения образцов в разных отечественных и зарубежных лабораториях.

Первые радиоуглеродные датировки (СОАН-4981, 5049) были получены по пробам, отобранным автором статьи в могилах 1 и 2 кургана № 33 поздней группы погребальных объектов памятника Яломан-II, которые, как уже отмечено, были отнесены на основе типологического анализа инвентаря к верх-уймонскому этапу булан-кобинской культуры. Полученные показатели [3. С. 268-269] потребовали уточнений, так как они противоречили датировке исследованного археологического комплекса, существенно удревняя его. Имевшиеся данные могли свидетельствовать лишь о том, что могилы действительно сооружены позже объектов ранней группы, исследованных на памятнике Яломан-II и относящихся к хуннускому (сюннускому) времени [10, 11 и др.]. Для проверки и увеличения количества результатов в другие лаборатории было отправлено несколько образцов из курганов № 31-33, которые относятся к верх-уймонскому этапу булан-кобинской культуры. Полученные данные подробно опубликованы в одной из монографий автора [3. С. 262-277], поэтому здесь они представлены в обобщенном варианте.

Le-7432. Яломан-II. Курган № 33, могила-2. Кости

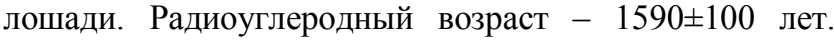
Суммированные калибровочные данные выглядят следующим образом: по $1 \delta$ (sigma) cal AD 361 (433) 598; по $2 \delta$ (sigma) cal AD 240 (433) 656.

GU-14925. Яломан-II. Курган № 31. Фрагмент роговой накладки на лук. Радиоуглеродный возраст $1700 \pm 35$ лет. Калибровочные данные: по $1 \delta$ (sigma) cal AD 260 (344, 370, 379) 406; по $2 \delta$ (sigma) cal AD 244 (344, 370, 379) 424.

GU-14920. Яломан-II. Курган № 32. Фрагмент роговой пряжки. Радиоуглеродный возраст - 1715 \pm 35 лет. Калибровочные данные: по $1 \delta$ (sigma) cal AD $258(264,272,340)$ 390; по $2 \delta$ (sigma) cal AD 241 (264, 272, 340) 418.

Le-7647. Яломан-II. Курган № 30. Радиоуглеродный возраст - $1620 \pm 60$ лет. Калибровочные данные: по $1 \delta$ (sigma) cal AD 387 (425) 534; по $2 \delta$ (sigma) cal AD 259 (425) 597.

Приводимые калибровочные показатели радиоуглеродных дат были тогда получены автором при использовании специальной программы, разработанной в лаборатории Вашингтонского университета (RADIOCARBON CALIBRATION PROGRAMM REV 4.3). Peзультаты, зафиксированные независимо друг от друга в двух разных лабораториях, подтвердили датировку, обозначившуюся в ходе археологических исследований. Эту же тенденцию продемонстрировала и опубликованная серия калиброванных радиоуглеродных дат, полученная по костям из погребений памятника ВерхУймон [16]. Такие данные оказались важны для изучения позднего этапа булан-кобинской культуры. Они укладываются в рамки обозначенного верх-уймонского этапа и времени существования Жужанского каганата.

Работа по получению радиоуглеродных, а также и дендрохронологических датировок должна быть продолжена. Совсем недавно имеющиеся сведения пополнились новыми датами, которые были получены в Аналитическом центре изотопных исследований Института мониторинга климатических и экологических систем (ИМКЭС) СО РАН (г. Томск). Радиоуглеродный анализ проведен жидкостно-сцинтилляционным методом с помощью спектрометра-радиометра Quantulus (Томский Центр коллективного пользования Сибирского отделения РАН). Калибровка радиоуглеродного возраста в календарные показатели произведена с помощью программы OxCal 3 (аналитик - канд. техн. наук Г.В. Симонова).

ИМКЭС-14С796. Яломан-II. Курган № 29. Кости

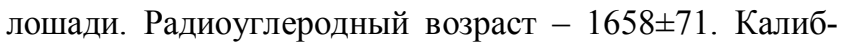
ровочные данные: по $1 \delta$ (sigma) (68,2\%) 250-530 AD; по $2 \delta$ (sigma) $(95,4 \%)$ 220-570 AD.

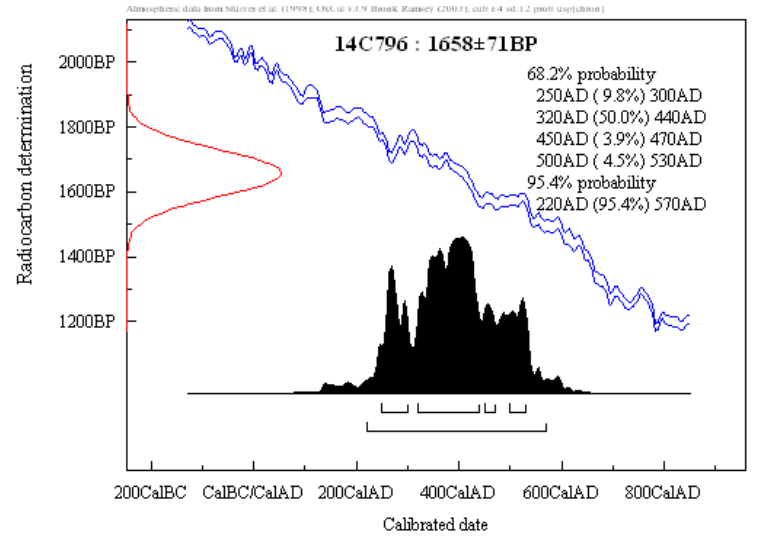

ИМКЭС-14С990. Яломан-II. Курган № 29. Кости

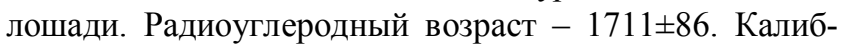
ровочные данные: по $1 \delta$ (sigma) (68,2\%) 230-430 AD; по $2 \delta$ (sigma) $(95,4 \%) 120-540 \mathrm{AD}$.

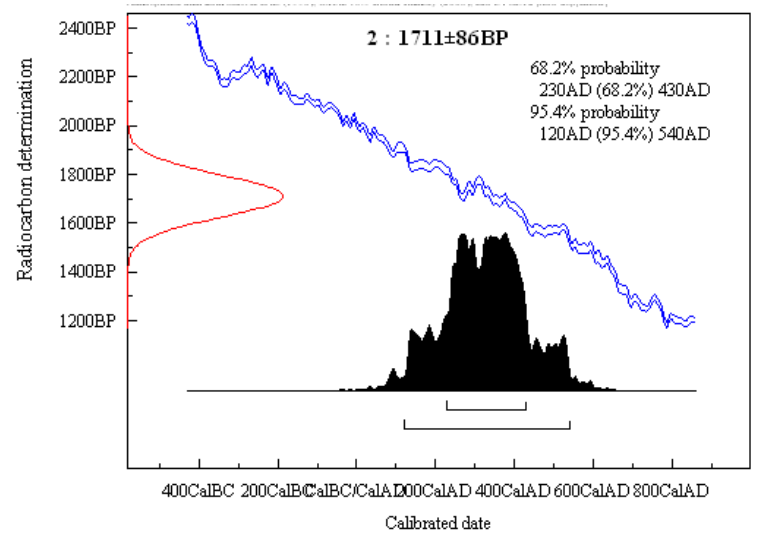

Одной из важных задач реализуемой программы являлось выяснение датировок курганов, в которых были найдены деревянные основы жестких седел без стремян [11. С. 64-74. Рис. 84-90]. Для этого в лабораторию $14 \mathrm{XРОНО} \mathrm{Центра} \mathrm{по} \mathrm{изучению} \mathrm{климата,} \mathrm{окружающей}$ среды и хронологии Королевского университета Белфаста (Великобритания) (14CHRONO Centre, Queens University, 
Belfast) были отправлены шесть образцов из двух объектов (№ 29 и 33). В ходе проведенного AMS-датирования зафиксированы результаты, позволяющие не только решать часть имеющихся проблем, но и наметить дальнейшие пути для эффективных исторических реконструкций. Приводимые калибровочные показатели получены при использовании специальной программы (RADIOCARBON CALIBRATION PROGRAMM CALIB REV7.0.0).

UBA-31066. Яломан-II. Курган № 29. Фрагмент ткани от футляра колчана. Радиоуглеродный возраст $1680 \pm 24$. Калибровочные данные: по $1 \delta$ (sigma) (68,3\%) cal AD 345-396 (1.000); по $2 \delta$ (sigma) $(95,4 \%)$ cal AD 262-277 (0.050), 328-416 (0.950).

UBA-31067. Яломан-II. Курган № 29. Фрагмент древесины от основы седла. Радиоуглеродный возраст $1692 \pm 29$. Калибровочные данные: по $1 \delta$ (sigma) $(68,3 \%)$ cal $\mathrm{AD}$ 269-270 (0.020), 332-396 (0.980); по $2 \delta$ (sigma) (95,4\%) cal AD 256-299 (0.174), 318-413 (0.826).

UBA-31068. Яломан-II. Курган № 29. Фрагмент кожи от уздечного ремня. Радиоуглеродный возраст 1944 \pm 30 . Калибровочные данные: по $1 \delta$ (sigma) (68,3\%) cal AD 20-85 (1.000); по $2 \delta$ (sigma) $(95,4 \%)$ cal BC 20 12 (0.015), 1- cal AD 127 (0.985).

UBA-31069. Яломан-II. Курган № 29. Фрагмент древка стрелы. Радиоуглеродный возраст - $1711 \pm 29$. Калибровочные данные: по $1 \delta$ (sigma) $(68,3 \%)$ cal $\mathrm{AD}$ 260-279 (0.232), 325-385 (0.768); по $2 \delta$ (sigma) (95,4\%) cal AD 252-308 (0.336), 310-395 (0.664).

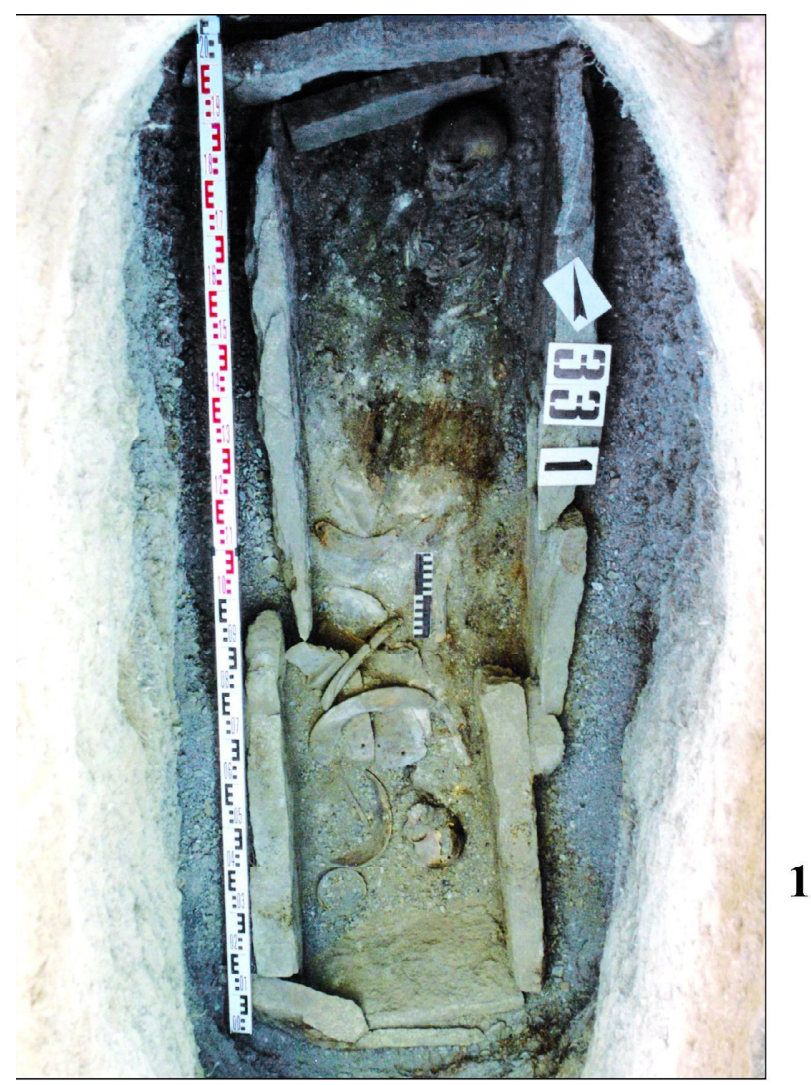

UBA-31070. Яломан-II. Курган № 29. Фрагмент древесины от пенала. Радиоуглеродный возраст $1810 \pm 32$. Калибровочные данные: по $1 \delta$ (sigma) (68,3\%) cal AD 139-198 (0.595), 206-242 (0.405); по $2 \delta$ (sigma) (95,4\%) cal AD 127-259 (0.890), 280-325 (0.110).

UBA-31071. Яломан-II. Курган № 33, могила-1. Фрагмент древесины от основы седла. Радиоуглеродный возраст $-2042 \pm 30$. Калибровочные данные: по $1 \delta$ (sigma) (68,3\%) cal BC 92-67 (0.248), 64 - cal AD 2 (0.752); по $2 \delta$ (sigma) $(95,4 \%)$ cal BC 163-129 (0.085), 120 - cal AD 25 (0.914), cal AD 44-45 (0.001).

Представленные результаты и серия предыдущих радиоуглеродных датировок позволяют угочнить хронологию появления и бытования обнаруженных предметов и объектов. Наличие таких дат создает основу для дальнейшего эффективного проведения дендрохронологических исследований на основе многочисленных находок из древесины в курганах памятника Яломан-II [11]. Данному обстоятельству способствует компактная планиграфия могильника, судя по которой самым ранним из раскопанных объектов является курган № 29. К нему в относительно короткий срок были пристроены другие [Там же. Рис. 7, 55], в том числе курган № 33 (рис. 1), где обнаружена хорошо сохранившаяся деревянная основа жесткого седла без стремян (рис. 2). Полученные абсолютные датировки позволяют заключить, что яломанский тип седла появился и использовался раньше так называемого древнетюркского и может быть датирован второй половиной $\mathrm{IV}$ - началом $\mathrm{V}$ в. н.э.

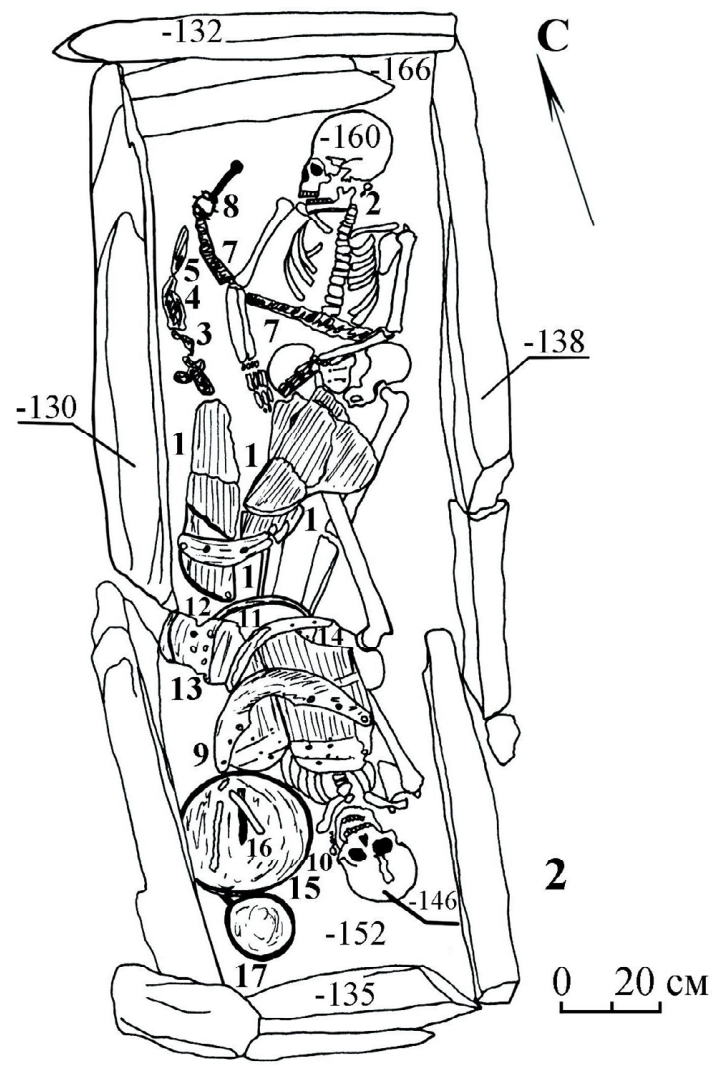



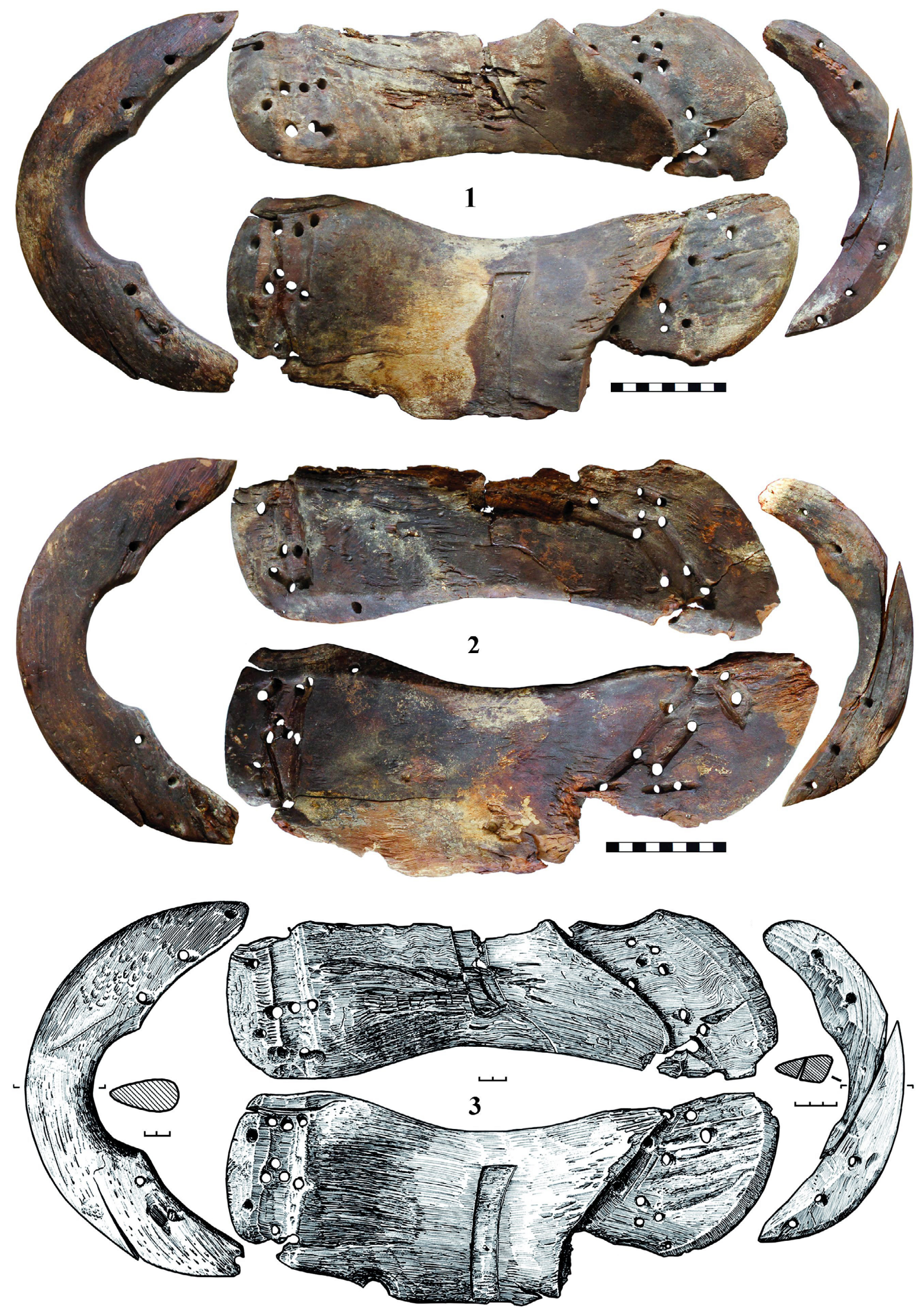

Рис. 2. Яломан-II. Курган № 33. Могила-1. Полный комплект деревянной основы жесткого седла (полки и луки): 1 - лицевая сторона деталей деревянной основы жесткого седла;

2 - оборотная сторона деталей деревянной основы жесткого седла; 3 - графические иллюстрации (по: [11. Рис. 84]) 
Таким образом, полученная аналитическая база по хронологии рассмотренных объектов создает основу для более детального анализа всех находок предтюркского периода, обнаруженных на памятнике Яломан-II. Необ- ходимо продолжить работу по системному AMSдатированию и проведению дендрохронологических исследований, что будет способствовать решению комплекса культурно-хронологических и исторических проблем.

\section{ЛИТЕРАТУРА}

1. Савинов Д.Г. Ранние кочевники Верхнего Енисея (археологические культуры и культурогенез). СПб. : Изд-во СПб. ун-та, 2002. 204 с. : ил.

2. Соенов В.И. Археологические памятники Горного Алтая гунно-сарматской эпохи (описание, систематика, анализ). Горно-Алтайск : РИО ГАГУ, 2003. $160 \mathrm{c}$.

3. Тишкин А.А. Создание периодизационных и культурно-хронологических схем: исторический опыт и современная концепция изучения древних и средневековых народов Алтая. Барнаул : Изд-во Алт. ун-та, 2007. 356 с.

4. Савинов Д.Г. Народы Южной Сибири в древнетюркскую эпоху. Л. : Изд-во ЛГУ, 1984. 174 с.

5. Кляшторный С.Г., Савинов Д.Г. Степные империи древней Евразии. СПб.: Филол. ф-т СПбГУ, 2005.346 с. (Исторические исследования).

6. Мамадаков Ю.Т. Культура населения Центрального Алтая в первой половине І тыс. н.э. : автореф. ... канд. ист. наук. Новосибирск, 1990. $19 \mathrm{c}$.

7. Тишкин А.А. Булан-кобинская культура Алтая: краткая история изучения и современное содержание // Культура как система в историческом контексте : Опыт Западно-Сибирских археолого-этнографических совещаний. Томск : Аграф-Пресс, 2010. С. $294-297$.

8. Тишкин А.А., Горбунов В.В. Комплекс памятников в долине р. Бийке (Горный Алтай). Барнаул : Изд-во Алт. ун-та, 2005.200 с. + вкл.

9. Тишкин А.А. О необходимости междисциплинарного изучения материалов гунно-сарматского времени Горного Алтая // Комплексные исследования древних и традиционных обществ Евразии. Барнаул : Изд-во Алт. ун-та, 2004. С. $296-300$.

10. Тишкин А.А., Горбунов В.В. Исследования погребально-поминальных памятников кочевников в Центральном Алтае // Проблемы археологии, этнографии, антропологии Сибири и сопредельных территорий. Новосибирск : Изд-во Ин-та археологии и этнографии СО РАН, 2003. T. IX, ч. I. C. $488-493$.

11. Тишкин А.А., Мыльников В.П. Деревообработка на Алтае во II в. до н.э. - V в.н.э. (по материалам памятников Яломан-ІІ и Бош-Туу-I). Барнаул : Изд-во Алт. ун-та, 2016. 192 с.: ил. (Археологические памятники Алтая. Вып. 2).

12. Воробьев М.В. Маньчжурия и Восточная Внутренняя Монголия (с древнейших времен до IX в. включительно). Владивосток : Дальнаука, 1994. $410 \mathrm{c}$

13. Кычанов Е.И. Кочевые государства от гуннов до маньчжуров. М. : Вост. лит., 1997. 319 с.

14. Крадин Н.Н. Общественный строй Жужаньского каганата // История и археология Дальнего Востока: к 70 -летию Э.В. Шавкунова. Владивосток : Изд-во ДВГУ, 2000. С. 80-94.

15. Соенов В.И., Эбель А.В. Курганы гунно-сарматской эпохи на Верхней Катуни. Горно-Алтайск : РИО ГАГПИ, 1992.116 с.

16. Соенов В.И., Трифанова С.В., Вдовина Т.А., Черепанов М.А. Раскопки погребений гунно-сарматской эпохи на могильнике Верх-Уймон в 2003-2004 гг. // Сохранение и изучение культурного наследия Алтая. Барнаул : Изд-во Алт. ун-та, 2005. Вып. XIV. С. 169-171.

\section{Tishkin Alexey A. Altai State University (Barnaul, Russia).E-mail: tishkin210@mail.ru}

\section{THE RESULTS OF THE RADIOCARBON DATING OF THE BURIAL MOUNDS OF THE ZHUZHAN TIMES OF THE} YALOMAN-II MONUMENT (CENTRAL ALTAI).

Keywords: Altai; mound; Zhuzhan time; radiocarbon dating.

Information about the Zhuzhansk Kaganate which dominated in Inner Asia from the second half of the 4th century A.D. till the defeat of the Turks in the middle of the 6th century is found in Chinese written sources. At the same time, there are very few archaeological materials about this nomadic state. This state of affairs is usually explained by the poor knowledge of the monuments of the pre-Türkic period on the territory of Mongolia. Ancient objects dating from the Zhuzhan time are excavated in Altai. Among them, the Yaloman-II funeral complex is of particular importance. It was studied under the guidance of the author of the article during several field seasons in the first decade of the 21 st century. Of the six unrestored barrows, a significant number of finds were found in various items of material culture, reflecting individual spheres of the existing life support system. Complexes of weapons and military equipment were consistently introduced into scientific circulation. They served as the initial basis for determining the chronological framework for the construction of excavated burials. The existing analogies and the typological analysis of the surviving products, as well as the undertaken radiocarbon dating allowed us to fill with a specific content the highlighted late (Upper-Uimon) stage of the Boulogne-Cuban archaeological culture. The most unexpected and important finds on the Yaloman-II monument were the discovered parts of the wooden foundations of hard saddles without stirrups. To determine the time of their creation and use, as well as to determine the chronology of the total number of burial mounds, most of which are related to each other, six samples were sent to the 14XRONO laboratory of the Center for Climate, Environment and Chronology Studies of Queen's University of Belfast (Great Britain) Objects (Nos. 29 and 33). In the course of the AMS-dating, results were obtained that allow not only solving part of the tasks set, but also outlining of further ways for effective historical reconstructions. Demonstration and analysis of a series of radiocarbon dating obtained in different laboratories, as well as comparing them with the results of a traditional archaeological approach in determining the chronology of archaeological objects, were the main goals of the scientific work presented in the article. The presence of initial absolute dates is also necessary for carrying out dendrochronological studies on the basis of numerous finds made of wood. In addition, it was possible to build a chronological scheme for the construction of funerary objects on the Yaloman-II monumen (Altai), which gave a significant number of findings in the pre-Türkic period. It is necessary to continue the work on the systematic production of radiocarbon dates and their calibrated values within the framework of the Zhuzhan period. As the practice of modern research shows, the presence of AMS-dating results allows more accurate determining of the chronological range of excavated burials. This also applies to the considered barrows which at the present stage can be referred to the end of the 4 th - beginning of the 5th century.

\section{REFERENCES}

1. Savinov, D.G. (2002) Rannie kochevniki Verkhnego Eniseya (arkheologicheskie kul'tury i kul'turogenez) [Early Nomads of the Upper Yenisei (Archaeological Cultures and Culturogenesis)]. St. Petersburg: St. Petersburg State University.

2. Coenov, V.I. (2003) Arkheologicheskie pamyatniki Gornogo Altaya gunno-sarmatskoy epokhi (opisanie, sistematika, analiz) [Archaeological Monuments of the Altai Mountains of the Hunno-Sarmatian Epoch (Description, Systematics, Analysis)]. Gorno-Altaysk: Gorno-Altaysk State University. 
3. Tishkin, A.A. (2007) Sozdanie periodizatsionnykh i kul'turno-khronologicheskikh skhem: istoricheskiy opyt i sovremennaya kontseptsiya izucheniya drevnikh i srednevekovykh narodov Altaya [Periodisation and Cultural and Chronological Schemes: Historical Experience and Modern Concept of Studying Ancient and Medieval Peoples of Altai]. Barnaul: Altai State University.

4. Savinov, D.G. (1984) Narody Yuzhnoy Sibiri v drevnetyurkskuyu epokhu [Peoples of Southern Siberia in the Ancient Turkic Era]. Leningrad: Leningrad State University.

5. Klyashtornyy, S.G. \& Savinov, D.G. (2005) Stepnye imperii drevney Evrazii [Steppe Empires of Ancient Eurasia]. St. Petersburg: St. Petersburg State University.

6. Mamadakov, Yu.T. (1990) Kul'tura naseleniya Tsentral'nogo Altaya v pervoy polovine I tys. n.e. [Culture of the Population of Central Altai in the early 1 st millennium AD]. Abstract of History Cand. Diss. Novosibirsk.

7. Tishkin, A.A. (2010) Bulan-kobinskaya kul'tura Altaya: kratkaya istoriya izucheniya i sovremennoe soderzhanie [Bulan-Kobin culture of Altai: A short history of study and contemporary content]. In: Chernaya, M.P. (ed.) Kul'tura kak sistema v istoricheskom kontekste: Opyt ZapadnoSibirskikh arkheologo-etnograficheskikh soveshchaniy [Culture as a System in the Historical Context: Experience of the West Siberian Archaeological and Ethnographic Meetings]. Tomsk: Agraf-Press. pp. 294-297.

8. Tishkin, A.A. \& Gorbunov, V.V. (2005) Kompleks pamyatnikov v doline r. Biyke (Gornyy Altay) [A Complex of Monuments in the Valley of the River Biyka (Mountainous Altai)]. Barnaul: Altai State University.

9. Tishkin, A.A. (2004) O neobkhodimosti mezhdistsiplinarnogo izucheniya materialov gunno-sarmatskogo vremeni Gornogo Altaya [On the need for an interdisciplinary study of the Hunno-Sarmatian period in Gorny Altai]. In: Kiryushin, Yu.F. \& Tishkin, A.A. (eds) Kompleksnye issledovaniya drevnikh $i$ traditsionnykh obshchestv Evrazii [Complex Studies of Eurasian Ancient and Traditional Societies]. Barnaul: Altai State University. pp. 296-300.

10. Tishkin, A.A. \& Gorbunov, V.V. (2003) Issledovaniya pogrebal'no-pominal'nykh pamyatnikov kochevnikov v Tsentral'nom Altae [The studies of nomadic burial monuments in the Central Altai]. In: Derevyanko, A.P. \& Molodin, V.I. (eds) Problemy arkheologii etnografii, antropologii Sibiri $i$ sopredel'nykh territoriy [Problems of Archeology, Ethnography, Anthropology of Siberia and Adjacent Territories]. Vol. 9(1). Novosibirsk: Institute of Archeology and Ethnography, SB RAS. pp. 488-493.

11. Tishkin, A.A. \& Mylnikov, V.P. (2016) Derevoobrabotka na Altae vo II v. do n.e. - V v.n.e. (po materiala pamyatnikov Yaloman-II i Bosh-Tuu-I) [Woodworking in the Altai in the 2nd century BC - 5th century AD (based on the material of Yaloman-II and Bosch-Tuu-I monuments of)]. Barnaul: Altai State University.

12. Vorobyev, M.V. (1994) Man'chzhuriya i Vostochnaya Vnutrennyaya Mongoliya (s drevneyshikh vremen do IX v. vklyuchitel'no) [Manchuria and Eastern Inner Mongolia (From Ancient Times to the 9th Century)]. Vladivostok: Dal'nauka.

13. Kychanov, E.I. (1997) Kochevye gosudarstva ot gunnov do man'chzhurov [Nomadic States From the Huns to the Manchus]. Moscow: Vostochnaya literatura.

14. Kradin, N.N. (2000) Obshchestvennyy stroy Zhuzhan'skogo kaganata [Public structure of the Zhuzhan Kaganate]. In: Kradin, N.N., Krupyanko, A.A. \& Sovasteev, V.V. (eds) Istoriya i arkheologiya Dal'nego Vostoka: $k$ 70-letiyu E.V. Shavkunova [History and Archeology of the Far East: To the 70th Anniversary of E.V. Shavkunov]. Vladivostok: Far East State University. pp. 80-94.

15. Soenov, V.I. \& Ebel, A.V. (1992) Kurgany gunno-sarmatskoy epokhi na Verkhney Katuni [Hunno-Sarmatian Mounds on the Upper Katun]. GornoAltaysk: Gorno-Altaysk State Pedagogical University.

16. Soenov, V.I., Trifanova, S.V., Vdovina, T.A. \& Cherepanov, M.A. (2005) Raskopki pogrebeniy gunno-sarmatskoy epokhi na mogil'nike VerkhUymon v 2003-2004 gg. [Excavations of Hunno-Sarmatian burials on the Verkh-Uymon burial ground in 2003-2004]. In: Kubrina, G.A. \& Semibratov, V.P. (eds) Sokhranenie i izuchenie kul'turnogo naslediya Altaya [Preservation and Study of the Altai Cultural Heritage]. Issue 14. Barnaul: Altai State University. pp. 169-171. 